\title{
TECHNIQUE OF MURAL PAINTINGS FROM THE TOURNAI CATHEDRAL
}
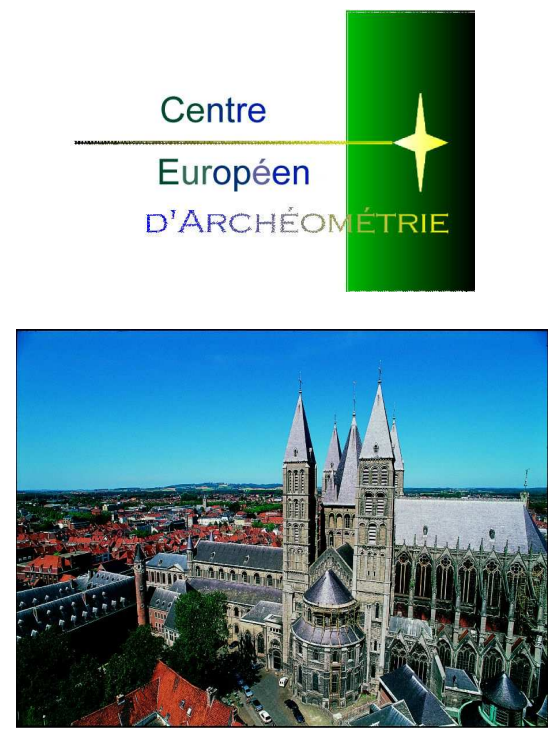

The Cathedral Notre-Dame of Tournai
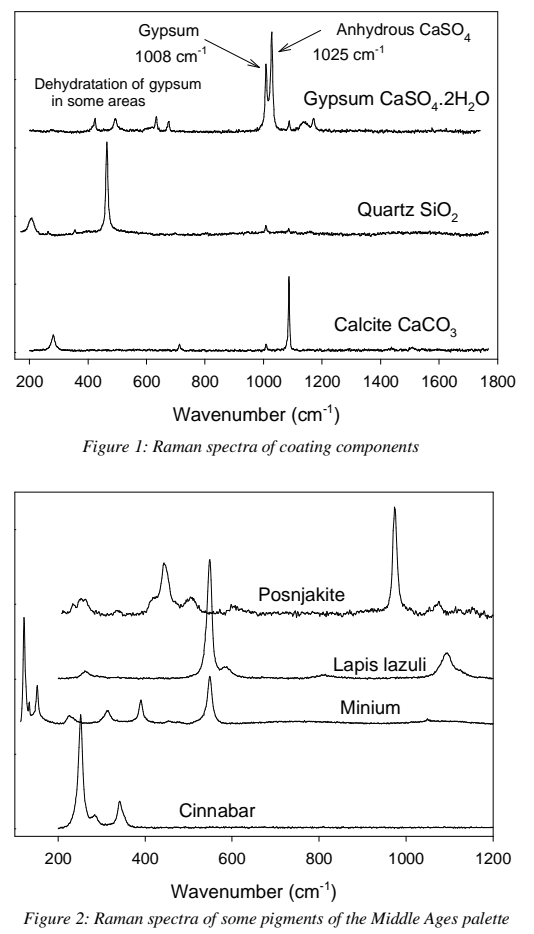

L. Lepot*, S. Denoël** and B. Gilbert*

* Analytical Chemistry and Electrochemistry, Bldg. B6C, Sart Tilman, Liège, B-4000 **European Center of Archaeometry. Bldg. B5, Sart Tilman, Liège, B-4000

\section{Introduction}

The Cathedral Notre-Dame of Tournai is one of the most beautiful religious edifice of Belgium. Long of 134 meters, it is the largest church of the country and one of the precursor of the Gothic cathedrals. In 2000, it was classified as UNESCO's World Inheritance. Three great historical periods have contributed to the actual appearance of the cathedral. The oldest parts are the nave and the transept, in Romanesque style. In 1243, the bishop of Tournai Gautier de Marvis (12191252) decided to replace the small Romanesque choir by a large gothic one, whose construction was completed in 1255 . During the Renaissance a portico and a choir screen were added. After a storm in 1999, the stability of the building was in danger and an important stabilization work has been initiated. A large part of the cathedral has been closed to the public and scaffoldings have been installed which allowed scientists to perform a closer examination of, among other features, residual wall paintings.

\section{Objectives}

The main objectives of our investigation are

- to identify the nature of the principal components of wall micro-fragments (various pigments and binders) by micro-Raman spectroscopy,

- to determine the original chromatic aspect of the different parts of the cathedral,

- to try to deduce a chronology in the numerous interventions through the centuries,

A hundred of micro-samples were examined originating first, from residuals of the architectonic decorations and secondly, from four wall paintings executed during the Romanesque period.

\section{Results}

\section{Major components}

Walls of the Tournai's Cathedral are covered by a standard coating of limestone, $\mathrm{CaCO}_{3}$, gypsum, $\mathrm{CaSO}_{4} \cdot 2 \mathrm{H}_{2} \mathrm{O}$ and quartz sand, $\mathrm{SiO}_{2}$, whose Raman spectra are presented in figure 1 . The mixture is applied to the masonry in order to fill in the depressions and the surface porosity of wall stones. It plays two different roles: protecting the natural stone from degradation, as a sacrificial layer, and preparing wall surfaces before any mural paintings. A stratigraphic study on a six-layered sample from the outside whitewash of the Cathedral surprisingly showed an identical composition in each layer. Thus, this multilayer patina seems to provide a grey appearance to the monument by interaction with light (1).

\section{Pigments}

Various pigments have been identified from their characteristic Raman spectra and the table 1 gives a list under chronological periods. Iron oxide is the most employed pigment in the Cathedral, as well as its hydrolyzed counterpart $\mathrm{Fe}(\mathrm{OH})_{3}$ which shades off the $\mathrm{Fe}_{2} \mathrm{O}_{3}$ red colour to ochre. The major conclusion of this survey is that all pigments correspond to a typically Middle Ages palette (some examples are shown in figure 2), and no contemporary intervention have been noticed. During the Romanesque period, lapis lazuli is largely used even in secondary zones such as in the triforium. We also found azurite in the capital of the Romanesque nave, but it is not sure that the investigated pictorial layer is the XIIth century original. In the Gothic period, the painters continued to use lapis lazuli, but it was progressively replaced by azurite (2).

\begin{tabular}{|c|l|l|}
\hline Yellow & \multicolumn{1}{|c|}{ Romanesque period } & \multicolumn{1}{c|}{ Gothic period } \\
\hline Orange & $\begin{array}{l}\text { Lead Yellow }(\mathrm{PbO}) \\
\text { Iron oxide }\left(\mathrm{Fe}_{2} \mathrm{O}_{3}-\mathrm{Fe}(\mathrm{OH})_{3}\right)\end{array}$ & $\begin{array}{l}\text { Minium }\left(\mathrm{Pb}_{3} \mathrm{O}_{4}\right) \\
\text { Iron oxide }\left(\mathrm{Fe}_{2} \mathrm{O}_{3}\right)\end{array}$ \\
\hline Red & $\begin{array}{l}\text { Cinnabar }(\mathrm{HgS}) \\
\text { Iron oxide }\left(\mathrm{Fe}_{2} \mathrm{O}_{3}\right)\end{array}$ & Cinnabar $\left(\mathrm{Fe}_{2} \mathrm{O}_{3}-\mathrm{Fe}(\mathrm{OH})_{3}\right)$ \\
\hline Green & $\begin{array}{l}\text { Posnjakite }\left(\mathrm{CuSO}_{4} \cdot 3 \mathrm{Cu}(\mathrm{OH})_{2} \cdot \mathrm{H}_{2} \mathrm{O}\right) \\
\text { Atacamite }\left(\mathrm{CuCl}_{2} \cdot 3 \mathrm{Cu}(\mathrm{OH})_{2}\right)\end{array}$ & \\
\hline Blue & $\begin{array}{l}\text { Lapis lazuli }\left(\mathrm{Na}_{8}\left[\mathrm{Al}_{6} \mathrm{Si}_{6} \mathrm{O}_{24} \mathrm{~S}_{\mathrm{n}}\right)\right. \\
\text { Azurite }(?)\left(2 \mathrm{CuCO}_{3} \cdot \mathrm{Cu}(\mathrm{OH})_{2}\right)\end{array}$ & $\begin{array}{l}\text { Azurite }\left(2 \mathrm{CuCO}_{3} \cdot \mathrm{Cu}(\mathrm{OH})_{2}\right) \\
\text { Lapis lazuli }\left(\mathrm{Na}_{8}\left[\mathrm{Al}_{6} \mathrm{Si}_{6} \mathrm{O}_{24}\right] \mathrm{S}_{\mathrm{n}}\right)\end{array}$ \\
\hline White & Lead white $\left(2 \mathrm{PbCO}_{3} \cdot \mathrm{Pb}(\mathrm{OH})_{2}\right)$ & Lead white $\left(2 \mathrm{PbCO}_{3} \cdot \mathrm{Pb}(\mathrm{OH})_{2}\right)$ \\
\hline Black & Carbon black & Carbon black \\
\hline
\end{tabular}

Table 1: Pigments found in Romanesque and Gothic parts of the Cathedral of Tournai
Beeswax and Egg yolk

Beeswax is referred to as a protecting agent, applied in the past to confer water-repellence to the external stone surface of Cathedrals. Water repellent and transpiring coatings insure the permeability of vapour but protect from any water infiltration, responsible of gypsum solubilization-crystallization processes which give rise to wall cracking (3). Since humidity is one of the main causes of decay for mural paintings, it is not surprising to find such organic traces. However, the fact that it has been easily detected (figure 3 ) can also be explained here by a modern conservation campaign as it is described in the Cathedral's archives.

Regarding the egg yolk (figure 3), it can be considered as binding medium for the surface layer of certain mural paintings and especially in the Sainte Marguerite's Legend.

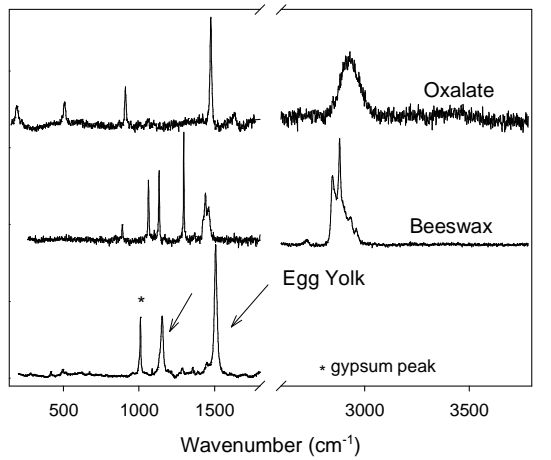

Calcium oxalate

The mural paintings show the presence of calcium oxalate on surface samples (figure 3), especially near green copper based pigments (posnjakite and atacamite) and lead white. It may be attributed to some metabolic processes due to the colonization of the surfaces by micro-organisms such as lichens, producing oxalic acid which in turn reacts with calcite to form a thin calcium oxalate membrane. In the Palazzo Farnese, the Frescoes painted in 1560 by Zuccari are very significantly damaged by the invasion of aggressive lichen colonies. This organism can produce up to $50 \%$ of its biomass as hydrated calcium oxalate, so destroying the platform on which the artwork is based (4).

\section{Acknowledgments}

The authors wish to thank S. Morris and L.Genicot for collecting most of the samples and for discussions. Finally, the French Community of Belgium and specially A. Matthys of the DGATLP ( Région wallonne) is acknowledged for financial support

\section{References}

1) $8^{\text {th }}$ FECS Conference, "Conservation of Ancient Monuments", Envir Sci \& Pollut Res, 2002, Special Issue 3, pp. 277-284. 2) H. Howard, Pigments of English Medieval Wall Painting, London, 2003

3) T.A. Cezar, "Calcium oxalate : A Surface Treatment for Limestone”, Journal of Conservation \& Museum Studies, 1998, vol. 4.

4) H.G.M. Edwards, "Probing history with Raman spectroscopy", The Analyst, 2004, vol. 129, pp.870-879. 